\title{
Assessment of the performance of a definition of a suspected measles case: implications for measles surveillance
}

\author{
Solange Artimos de Oliveira, ${ }^{1}$ Luiz Antonio Bastos Camacho, ${ }^{2}$ \\ Antonio Carlos de Medeiros Pereira, ${ }^{1}$ Sérgio Setúbal, ${ }^{1}$ Rita Maria \\ Ribeiro Nogueira, ${ }^{3}$ and Marilda Mendonça Siqueira ${ }^{4}$
}

Suggested citation Oliveira SA, Camacho LAB, Pereira ACM, Setúbal S, Nogueira RMR, Siqueira MM. Assessment of the performance of a definition of a suspected measles case: implications for measles surveillance. Rev Panam Salud Publica. 2006:19(4):229-35.

ABSTRACT Objective. To assess the performance, in Brazil, of the definition of a suspected measles case among patients with rash diseases that has been adopted in Brazil and many other countries. Methods. From January 1994 to December 2003, patients with acute rash were seen at two large primary health care units and a public general hospital in Niterói, a city in the metropolitan area of the city of Rio de Janeiro, Brazil. Data from clinical and serologic assessment were used to estimate sensitivity, specificity, positive predictive value (PPV), and negative predictive value (NPV) of the definition of a suspected measles case that has been adopted in Brazil, as well as other combinations of signs and symptoms; serologic status was taken as the reference. Using enzyme immunoassay, serum samples were tested for immunoglobulin $M(\operatorname{IgM})$ antibodies against measles virus.

Results. A total of 1221 patients with an illness characterized by different combinations of rash with other signs and symptoms were studied. The suspected case definition that has been adopted in Brazil (rash, fever, and at least one of the following: cough, coryza, or conjunctivitis) had an overall sensitivity of $100 \%$, and a specificity of $58.7 \%$. Confirmed measles cases were 2.4 times as likely as were other rash diseases to have that combination of signs/symptoms. The suspected case definition adopted in Brazil had a 6\% PPV and 100\% NPV. The combination of all five signs and symptoms had the highest specificity, PPV, and likelihood ratio, for both children ( $<15$ years old) and adults ( $\geq 15$ years). That was achieved at the expense of sensitivity, which dropped to $89 \%$, but the NPV was still very high.

Conclusions. Our results show that the suspected measles case definition adopted in Brazil is extremely sensitive for measles surveillance among patients with rash diseases. However, the high false-positive rates that were found may result in a substantial number of other rash diseases being misclassified as measles, leading to the misdirection of control measures and increases in their cost.

Key words Measles; exanthema; diagnosis, differential; predictive value of tests; population surveillance; Brazil.

1 Universidade Federal Fluminense, Hospital Universitário Antonio Pedro, Disciplina de Doenças Infecciosas e Parasitárias, Niterói, Rio de Janeiro, Brazil. Send correspondence to: Solange Artimos de Oliveira, Hospital Universitário Antonio Pedro, Disciplina de Doenças Infecciosas e Parasitárias, Rua Marquês do Paraná, 303, 2. andar, Niterói,
24030-210, Rio de Janeiro, Brazil; telephone: 5521 2629 9313; fax: 55212629 9311; e-mail: artimos@ vm.uff.br

2 Fundação Oswaldo Cruz, Escola Nacional de Saúde Pública, Rio de Janeiro, Rio de Janeiro, Brazil.
3 Fundação Oswaldo Cruz, Instituto Oswaldo Cruz, Departamento de Virologia, Rio de Janeiro, Rio de Janeiro, Brazil.

4 Fundação Oswaldo Cruz, Instituto Oswaldo Cruz, Departamento de Virologia, Laboratório de Vírus Respiratórios e Sarampo, Rio de Janeiro, Rio de Janeiro, Brazil. 
Despite the development of a successful live attenuated vaccine, measles remains the most frequent cause of vaccine-preventable childhood deaths in many developing countries. Further, there is a continuing threat of outbreaks in industrialized countries $(1,2)$. The disease continues to spread primarily whenever the level of vaccine coverage required to interrupt transmission is not reached and sustained. According to the World Health Organization, there are still about 700000 deaths from measles per year worldwide, predominantly in young children in less developed countries (2).

In Brazil, routine national measles vaccination was introduced following the creation of the National Immunization Program in 1973. However, because of the difficulty of achieving uniformly high coverage rates, measles was still a serious public health problem in the early 1990s and one of the leading causes of morbidity and mortality among young children (3).

In 1992 the Brazilian Ministry of Health carried out a countrywide mass vaccination campaign for measles, which resulted in a dramatic reduction in measles incidence rates across the country (3). In the following years, routine immunization, follow-up campaigns, and surveillance activities were not conducted effectively enough to prevent the buildup of susceptible individuals, and a measles epidemic occurred in 1997, with more than 53000 confirmed cases reported (4). The resurgence of measles in 1997 led to supplementary immunization activities as part of outbreak control. Countrywide follow-up campaigns were conducted in 1997, targeting children aged 6 months to 4 years, and in 2000, targeting children $1-4$ years old. The actual coverage achieved at the end of campaigns was $66 \%$ in 1997 and $100 \%$ in 2000. The last outbreak of measles in Brazil occurred in February 2000, with 15 cases occurring, primarily among unvaccinated children. Analysis of Brazilian surveillance data indicated that the interruption of indigenous measles transmission in Brazil in 2000 has been sustained through 2003 (5). The Region of the Americas now has the lowest measles incidence rate in the world (0.8 per 100 000). In Canada, Mexico, and the United States of America most of the 119 confirmed cases reported in 2003 and the 106 confirmed cases reported in 2004 were imported (6).

The success of measles elimination requires continued high-quality surveillance and high vaccination coverage (7). Case investigation and identification of contacts are now recommended for all suspected cases of measles. In order to trigger further investigation and laboratory or epidemiologic confirmation, the current definition of a suspected measles case that has been adopted in many countries (including by Brazil's Ministry of Health in 1992) relies on the presence of a generalized maculopapular rash of $\geq 3$ days' duration, fever, and at least one of the following: cough, coryza, or conjunctivitis $(3,8,9)$.

The performance of the definition of a suspected case is affected by the occurrence and distribution of measles and of other maculopapular febrile rashes that may be misdiagnosed as measles. When measles incidence is very low, a diagnosis based on clinical grounds alone is more likely to lead to confusing measles with other infectious exanthematous illnesses (10). Given the pivotal role that the definition of a suspected case has in measles surveillance, assessment of the performance of the definition is relevant since it may affect the effectiveness of the measles elimination program.

The objective of this study was to assess the accuracy of the definition of a suspected measles case that has been adopted in Brazil and many other countries.

\section{METHODS}

\section{Subjects and sample collection}

This study was conducted from January 1994 through December 2003 in the city of Niterói, which is in the metropolitan area of the city of Rio de Janeiro, Rio de Janeiro, Brazil. For the study, patients who had acute rash, and either with or without a fever (the eligibility criteria), who were receiving care at two large primary health care units and a public general hospital in Niterói were approached as follows: A standard clinical examination was performed, a clotted blood sample for serology was collected in a sterile glass tube at the time the patient was enrolled in the study, and written consent to use the data for research purposes was requested from the patient or that person's guardian. The three study sites were part of the public network and covered approximately 50\% of the Niterói population. The study protocol was approved by the hospital's research ethics committee.

Symptoms and signs (measured or reported fever, cough, coryza, conjunctivitis, and other symptoms) reported by study subjects were assessed by medical doctors at the time of enrollment. Signs and symptoms and their duration, sociodemographic data, and vaccination status were recorded on a form designed for the study. Regardless of other symptoms they had, patients with acute rash were investigated for exanthematous diseases under surveillance (measles, rubella, and dengue), as well as for parvovirus and human herpesvirus 6 (HHV-6).

\section{Laboratory tests}

All serum samples were tested for immunoglobulin M (IgM) antibodies against measles virus, using an antibody capture enzyme immunoassay (EIA) test: (i) during 1994-1998 an EIA developed at the Centers for Disease Control (CDC), Atlanta, Georgia, United States (11) and (ii) during 1999-2003 the Enzygnost Anti-Measles Virus/IgM commercial EIA (Dade Behring, Marburg, Germany). Previous reports have indicated those two EIAs are both sensitive and specific and have similar accuracy $(11,12)$.

Sera were also tested for rubella virus IgM antibodies using a commercial EIA test: (i) during 1994-1999 the Rubenostika II IgM EIA (Organon Teknika BV, Boxtel, the Netherlands) and (ii) during 2000-2003 the Enzygnost Anti-Rubella Virus/IgM EIA (Dade Behring, Marburg, Germany). In addition, sera were tested for dengue 
virus IgM antibodies: (i) during 19942001 with an in-house EIA $(13,14)$ and (ii) during 2002-2003 with the INDX IVD Microwell ELISA Dengue Fever IgM commercial EIA (Panbio, Inc., Columbia, Maryland, United States). Specimens negative for measles, rubella, and dengue virus IgM antibodies were also tested for human parvovirus IgM antibodies using an EIA: (i) during 1994-2001 with an in-house antibody capture EIA (15) and (ii) during 2002-2003 with the Parvovirus Enzyme Immunoassay commercial EIA (Biotrin, Dublin, Ireland). An in-house indirect immunofluorescence test for HHV-6 IgG (16) was also used to detect low-avidity HHV-6 IgG (indicating recent primary infection) in children less than 4 years of age who did not have an alternative diagnosis.

\section{Data analysis}

The degree to which the definition of a suspected measles case represented actual laboratory-defined cases (accuracy or validity) was assessed in terms of sensitivity and specificity. The sensitivity of the definition of a suspected case was estimated by the proportion of confirmed measles cases who presented the definition of a suspected case that the Brazilian Ministry of Health recommends for surveillance (3). Specificity was estimated by the proportion of all nonmeasles cases who did not present the definition of a suspected case. The likelihood ratio is the probability of a specified combination of signs and symptoms in those with measles divided by the probability of the combination in those without measles, that is, the sensitivity divided by the false-positive rate. The positive predictive value (PPV) was given by the proportion of patients seropositive for measles among those who met our definition of a suspected case. In addition to that definition, several combinations of signs and symptoms were analyzed, and their sensitivity, specificity, and PPV were compared. The negative predictive value (NPV) was also calculated for selected situations.

Patients were divided into measles cases and nonmeasles cases in order to assess the performance of the definition of a suspected measles case. Data analysis was stratified by: (i) age, to account for differences in the clinical presentation of measles in children (subjects less than 15 years of age) and adults, and (ii) by time period, acknowledging the distinct phases of surveillance and control of measles in Brazil. The entire study period (19942003) was split in two distinct periods: nonepidemic years (January 1994-July 1997 and March 1998-December 2003) and epidemic years (August 1997February 1998). Ninety-five percent confidence intervals (95\% CIs) for the estimates were constructed. Data were analyzed using Epi Info 6.04d software (17).

Following a thorough active investigation by the staff of the public health surveillance department, cases with a laboratory test that was positive for measles IgM antibodies and that were found to be related to a recent measlescontaining vaccine were excluded from this study (8).

\section{RESULTS}

From 1221 cases with rash enrolled between January 1994 and December 2003, we confirmed the diagnosis of measles in $31(2.5 \%)$, dengue fever in $354(29.0 \%)$, human parvovirus B19 in $120(9.8 \%)$, rubella in $104(8.5 \%)$, and HHV-6 in 63 (5.2\%). No laboratory diagnosis was established in 549 cases $(45.0 \%)$ who were seronegative for rubella, measles, dengue, parvovirus, and HHV-6. All the confirmed cases of measles occurred between August 1997 and February 1998. Most (28/31) of the confirmed measles cases were 15 years or more of age. Eight patients had a history of one dose of measles vaccine.

The suspected case definition adopted in Brazil and many other countries (rash, fever, and at least one of the following: cough, coryza, or conjunctivitis) had an overall sensitivity of 100\% (95\% CI: $88.9 \%-100.0 \%)$ and a specificity of $58.7 \%$ (95\% CI: $55.0 \%-$ $61.6 \%$ ) (Table 1). Confirmed measles cases were 2.4 times as likely (likelihood ratio $=1 /(1-0.59))$ as were other rash diseases to have that combination of signs/symptoms. The suspected case definition adopted in Brazil had a $6.0 \%$ PPV (95\% CI: $4.3 \%-8.8 \%$ ) and a $100 \%$ NPV (95\% CI: $99.4 \%-100 \%)$. This case definition performed slightly better in subjects 15 or more years of age than it did with children (Table 1). The combination of all five signs/ symptoms had the highest specificity, PPV, and likelihood ratio for both age groups That was achieved at the expense of sensitivity, which dropped to 90.0\% (95\% CI: 74.3\%-97.9\%), but NPV was still very high.

If only rash and fever were considered, sensitivity and NPV were still maximum, but specificity, PPV, and likelihood ratio dropped to very low levels (Table 1 and Table 2). Other combinations of signs and symptoms were studied (Table 1). Modified case definitions combining rash, fever, and at least two of cough, coryza, and conjunctivitis had high sensitivity values (around 90\%) and greater specificity (from $83.2 \%$ to $92.4 \%$ ) (Table 1). The PPVs and the likelihood ratios obtained with the combinations of exanthema and two of the signs of cough, coryza, or conjunctivitis were also better, especially in individuals aged 15 years or older (data not shown). The overall likelihood ratio in nonepidemic years for the combination of rash, fever, and coryza + conjunctivitis was 11.3 , and the ratio for the combination of rash, fever, and cough + conjunctivitis was 12.4 (Table 2). The overall likelihood ratio in nonepidemic years for subjects who were 15 or more years of age for the combination of rash, fever, and coryza + conjunctivitis was 22.8, and for the combination of rash, fever, and cough + conjunctivitis it was 22.7 (Table 2).

The sensitivity and specificity of the definition of a suspected case adopted by the Brazilian Ministry of Health were similar in measles epidemic years (from August 1997 to February 1998) (Table 3) and for the entire, 19942003 study period (Table 1). However, the results for PPV were higher in the epidemic years for the age group 15 years or older $(82.3 \%$ ) (Table 2 ). Similar results were obtained with the modified combinations of signs and symptoms studied above (Table 2). 
TABLE 1. Sensitivity and specificity of different combinations of exanthema and fever with other signs and symptoms for a suspected measles case definition, stratified by age, Niterói, Brazil, 1994-2003

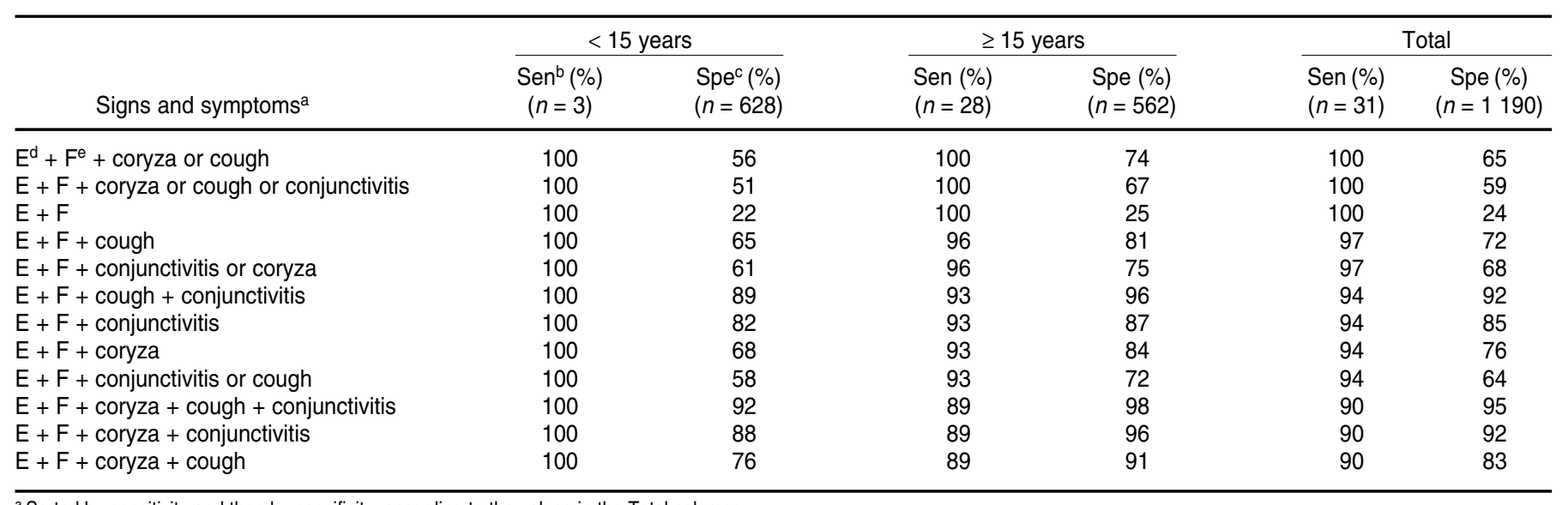

\footnotetext{
a Sorted by sensitivity and then by specificity, according to the values in the Total columns.

${ }^{\mathrm{b}}$ Sen $=$ sensitivity.

${ }^{\mathrm{S}} \mathrm{Spe}=$ specificity.

${ }^{\mathrm{d}} \mathrm{E}=$ exanthema.

${ }^{e} \mathrm{~F}=$ fever.
}

Over the entire study period, only 49 of the 522 cases that fulfilled the definition of a suspected measles case were notified by medical doctors as suspected measles cases. Of the 49,31 of them $(63.3 \%)$ were serologically confirmed as measles. Of the remaining 18 cases, no laboratory diagnosis was established in 9 cases, and 4 cases were confirmed as dengue, 4 as HHV-6, and 1 as rubella. Thirty-eight cases were notified in measles epidemic years, and only 11 cases during the nonepidemic years. All cases fulfilled the definition of a suspected case that had been adopted by the Brazilian Ministry of Health.

\section{DISCUSSION}

The performance of the definition of a suspected case impacts on the two levels of sensitivity of surveillance systems: detection of cases, and detection of epidemics. In this study the definition of a suspected case that was used in Brazil was extremely sensitive, detecting all measles cases that occurred in the study period.

However, the specificity was low $(58.7 \%)$, including in measles epidemic years $(59.6 \%)$. Although sensitivity is not affected by the incidence of disease, specificity may vary depending on the incidence of other exanthems (18). Many other infections can present with similar clinical symptoms, including rubella, parvovirus B19, roseola infantum, dengue fever, enteroviruses,

TABLE 2. Positive predictive value (PPV) and likelihood ratio of different combinations of exanthema and fever with other signs and symptoms for a suspected measles case definition, stratified by age, in epidemic years (August 1997-February 1998) and nonepidemic years (January 1994-July 1997 and March 1998-December 2003), Niterói, Brazil

\begin{tabular}{|c|c|c|c|c|c|c|c|c|c|c|c|c|}
\hline \multirow[b]{3}{*}{ Signs and symptoms ${ }^{a}$} & \multicolumn{6}{|c|}{ Nonepidemic years } & \multicolumn{6}{|c|}{ Epidemic years } \\
\hline & \multicolumn{3}{|c|}{ Likelihood ratio } & \multicolumn{3}{|c|}{$\mathrm{PPV}^{\mathrm{b}}(\%)$} & \multicolumn{3}{|c|}{ Likelihood ratio } & \multicolumn{3}{|c|}{ PPV (\%) } \\
\hline & $\begin{array}{c}<15 \\
\text { years }\end{array}$ & $\begin{array}{c}\geq 15 \\
\text { years }\end{array}$ & Total & $\begin{array}{l}<15 \\
\text { years }\end{array}$ & $\begin{array}{c}\geq 15 \\
\text { years }\end{array}$ & Total & $\begin{array}{l}<15 \\
\text { years }\end{array}$ & $\begin{array}{l}\geq 15 \\
\text { years }\end{array}$ & Total & $\begin{array}{c}<15 \\
\text { years }\end{array}$ & $\begin{array}{c}\geq 15 \\
\text { years }\end{array}$ & Total \\
\hline $\mathrm{E}^{\mathrm{c}}+\mathrm{F}^{\mathrm{d}}+$ cough + conjunctivitis & 9.4 & 22.7 & 12.4 & 4 & 53 & 24 & 10.7 & 18.6 & 12.2 & 50 & 96 & 88 \\
\hline$E+F+$ coryza + cough + conjunctivitis & 12.3 & 38.6 & 16.8 & 6 & 66 & 30 & 10.7 & 17.9 & 11.7 & 50 & 96 & 88 \\
\hline$E+F+$ coryza + cough & 4.2 & 10.0 & 5.4 & 2 & 33 & 12 & 0.0 & 4.5 & 11.7 & 100 & 86 & 88 \\
\hline$E+F+$ coryza + conjunctivitis & 8.6 & 22.8 & 11.3 & 4 & 53 & 23 & 8.0 & 17.9 & 9.4 & 43 & 96 & 85 \\
\hline$E+F+$ conjunctivitis & 5.6 & 7.1 & 6.0 & 3 & 26 & 14 & 4.6 & 0.0 & 6.9 & 30 & 100 & 81 \\
\hline$E+F+$ coryza or cough & 2.3 & 3.9 & 3.0 & 1 & 16 & 7 & 4.6 & 4.0 & 4.3 & 30 & 85 & 72 \\
\hline$E+F+$ cough & 2.8 & 5.1 & 3.5 & 1 & 20 & 8 & 4.0 & 3.9 & 3.9 & 27 & 84 & 70 \\
\hline$E+F+$ coryza & 3.1 & 5.9 & 3.8 & 1 & 23 & 9 & 3.6 & 4.6 & 3.7 & 25 & 87 & 69 \\
\hline$E+F+$ conjunctivitis or coryza & 2.6 & 3.9 & 2.6 & 1 & 16 & 7 & 2.7 & 3.2 & 2.8 & 20 & 82 & 63 \\
\hline$E+F+$ conjunctivitis or cough & 2.4 & 3.3 & 1.0 & 1 & 14 & 6 & 2.7 & 2.6 & 2.6 & 20 & 79 & 60 \\
\hline$E+F+$ coryza or cough or conjunctivitis & 2.1 & 3.0 & 2.4 & 1 & 13 & 6 & 2.1 & 3.3 & 2.5 & 17 & 82 & 60 \\
\hline$E+F$ & 1.3 & 1.3 & 1.3 & 1 & 6 & 3 & 1.3 & 1.2 & 1.3 & 11 & 64 & 43 \\
\hline
\end{tabular}

a Sorted by likelihood ratio in epidemic years and then in nonepidemic years, according to the values in the Total columns.

bPPV = positive predictive value.

${ }^{\mathrm{c}} \mathrm{E}=$ exanthema

${ }^{d} F=$ fever. 
TABLE 3. Sensitivity and specificity of different combinations of exanthema and fever with other signs and symptoms during epidemic years (August 1997-February 1998) for a suspected measles case definition, stratified by age, Niterói, Brazil

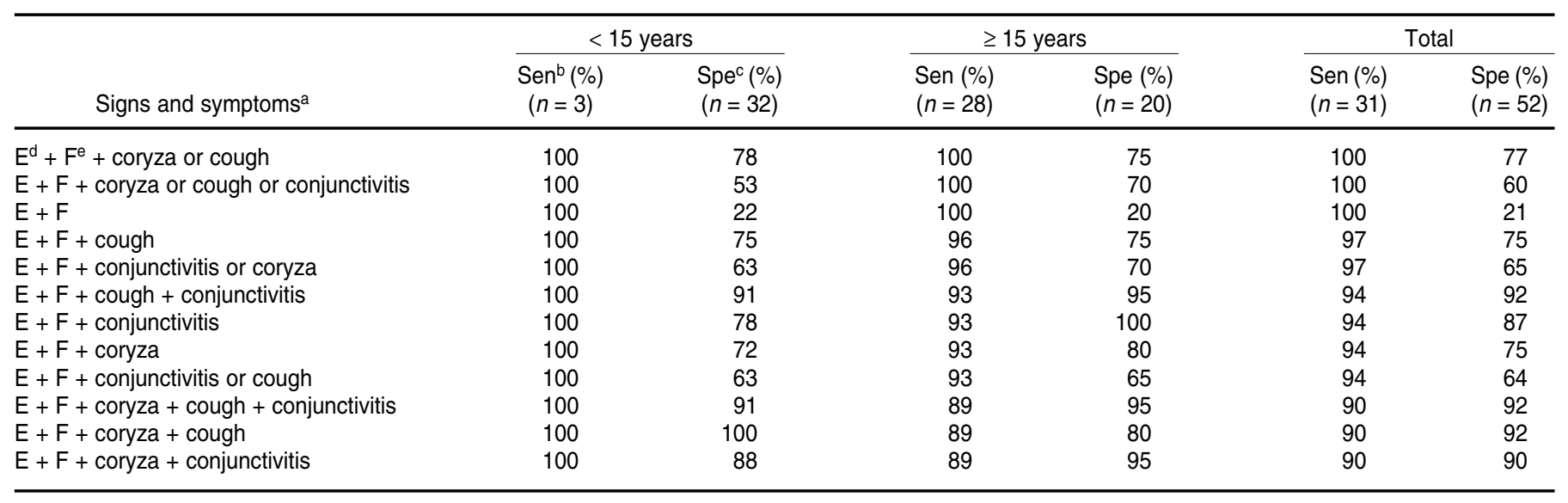

a Sorted by sensitivity and then by specificity, according to the values in the Total columns.

${ }^{\mathrm{b}}$ Sen $=$ sensitivity.

c Spe = specificity.

${ }^{\mathrm{d}} \mathrm{E}=$ exanthema.

${ }^{e} \mathrm{~F}=$ fever.

streptococci, and adenoviruses (19-22). As those diseases may meet the definition of a suspected measles case, accurate identification of measles becomes more difficult in low-incidence settings. Therefore, the sensitive suspected case definition adopted in Brazil to screen cases for investigation, along with the simultaneous occurrence of other rash diseases, may explain the low specificity observed in this study for epidemic and nonepidemic periods. In fact, for the whole study period and for both age groups the use of a modified suspected case definition (rash, fever, and at least two of the following: cough, coryza, or conjunctivitis) had high values for both sensitivity $(90.0 \%$ or higher) and specificity (from $83.2 \%$ to 92.4\%) (Table 1). Although serological confirmation is essential to ensure an accurate diagnosis of measles when the disease is rare (18), the use of a modified suspected case definition might be useful in measles surveillance when serum samples are not available.

Other studies have also shown that for countries with good measles control, the definition of a suspected case that has been adopted in Brazil lacks specificity $(18,23-25)$. In settings of low measles incidence the PPV of this measles case definition is also low. In addition, an increased proportion of measles cases may have a mild presentation that does not meet that sus- pected case definition (such as may happen with modified disease in vaccinated persons) (18). In our study the overall PPV of the suspected case definition adopted by the Brazilian Ministry of Health was not much better than the results obtained in other studies $(18,24)$. However, although the PPV values were higher during the epidemic years, the best results were still seen for the modified case definitions that combined rash, fever, and at least two of the following: cough, coryza, or conjunctivitis. This was especially true for the individuals who were 15 years old or older.

The results of our work have shown that the suspected measles case definition adopted by the Brazilian Ministry of Health is extremely sensitive for measles surveillance among patients with rash diseases. The prompt recognition of a suspected case was pivotal for timely investigation and effective control measures, including active search for additional cases. When measles is close to elimination, the aim of surveillance is to detect all cases and to prevent a potential outbreak (24-28). Therefore, the consequences of missing a suspected case of measles (that is, having a false negative diagnosis) are much more severe than is true for defining as a suspected case of measles an individual with another illness (having a false positive diagnosis).
That is because these false positive subjects are more likely to be detected by highly specific laboratory tests and patient follow-up. However, high false positive diagnosis rates result in a substantial number of other rash diseases being misclassified as measles, leading to the misdirection of control measures and increases in their cost. Rash may occur in approximately $5 \%$ of recipients 7-10 days after they receive a measles vaccination. The measles vaccination induces IgM antibodies that are indistinguishable from the antibodies resulting from natural infection (29).

Confirmation by epidemiological link with laboratory-confirmed cases strengthens the role of the suspected case definition and reinforces the need for accurate and timely verification of the signs and symptoms. The size of an outbreak may be overestimated if many cases of febrile rash illness are counted by indirect confirmation.

An enhanced case definition that includes all cases of fever and generalized maculopapular rash is supported on the grounds that the increase in sensitivity would justify the decreased specificity (30). In fact, that is the working definition of suspected cases in England and Wales (24). This definition is more inclusive than the one adopted in Brazil and many other countries (fever and generalized maculopapular rash and conjunctivitis or cough or coryza) 
(18, 23-25). The Pan American Health Organization (PAHO) promotes a fully integrated approach to measles and rubella surveillance, and PAHO is also concerned about younger health professionals who may be unfamiliar with measles. Therefore, PAHO supports a suspected case definition that consists of rash and fever or "when a health professional suspects measles or rubella" (31). That fits the notion of syndromic surveillance, which may be more efficient for controlling rash diseases. Although the syndrome of rash febrile illness may include dengue and other infections of public health relevance, only measles and rubella are discussed in this study because of logistical and epidemiological reasons beyond the scope of this paper.

The eligibility criterion for the study (patients with acute rash) was more inclusive than in routine surveillance, which requires fever and other signs and symptoms besides rash in order to characterize a suspected measles case (3). The criterion adopted in this study was possibly more sensitive to atypical measles with mild, abbreviated illness. These attenuated forms may occur (i) in the presence of low levels of maternal transplacental antibody, (ii) after administration of immunoglobulin, or (iii), rarely, following reinfection after natural infection or vaccination (32). Still, the study sample was selected following two important criteria: (i) rash, one of the signs that is included in the suspected measles case definition, and (ii) the subjects' access to health care. We lack data on subjects without rash, so the estimates of accu- racy of the other signs/symptoms are subject to the so-called "verification bias." This kind of selection bias has been disregarded in other papers addressing issues similar to those of our paper $(18,24)$. It seems intuitive and logical to start the detection of measles with rash, which is the most characteristic feature of measles, and to look for other signs/symptoms only in those patients fulfilling that criterion (acute rash). We thus ended up with a serial combination of criteria (rash and different combinations of other signs/ symptoms), for which the sensitivity should not be much different from our estimates. That is because measles without rash (false-negatives, as with immunocompromised individuals) seems to be very rare. Conversely, the specificity may have been affected by the selection of cases with rash. In this study the specificity of fever + cough/conjunctivitis/coryza may appear lower because the study group included other rash diseases that present signs and symptoms found in measles.

As with many other laboratory tests that measure antibody response, the EIA's accuracy is expected to vary as the disease progresses, with accuracy being lower in the early course of infection. Our Brazil study group was still heterogeneous in terms of timing of clinical and laboratory assessment, and of disease severity, despite the fact that cases without rash were excluded. Moreover, in the vast majority of cases the clinical presentation relied on just one contact between the patient and a physician, and so any other signs and symptoms that might have developed later were not taken into account. Nevertheless, those considerations probably enhance the usefulness of the results that we have presented.

Our Brazil study also showed that all 31 confirmed measles cases were notified by medical doctors as suspected measles cases, although the 522 cases that fulfilled the suspected case definition were approximately 17 times as numerous. Besides, it seems that the low incidence of measles resulting from mass vaccination campaigns has not affected the accuracy of health care workers' diagnoses of measles. Our results have shown that it will be important to maintain and assess the established surveillance system since the incidence of measles varies over time and among countries, requiring different approaches to the use of clinical and laboratory case definitions (18).

Acknowledgements. We gratefully acknowledge Dr. Jussara P. Nascimento for performing the human parvovirus B19 test. For their clinical support, we thank the general practitioners from the Disciplina de Doenças Infecciosas e Parasitárias/ Hospital Universitário Antonio Pedro, the Policlínica Comunitária Santa Rosa, and the Centro de Saúde Carlos Antonio da Silva, which are all in Niterói, Rio de Janeiro, Brazil. We also acknowledge the Conselho Nacional de Pesquisa e Desenvolvimento (CNPq grants No. 302430/2002-4 and No. 471155/03-9) for providing financial support for the research.

\section{REFERENCES}

1. Griffin DE, Bellini WJ. Measles virus. In: Fields BN, Knipe DM, Howley PM, eds. Fields virology. 3rd ed. Philadelphia: LippincottRaven Publishers; 1996. Pp. 1267-1312.

2. Duke T, Mgnone CS. Measles: not just another viral exanthem. Lancet. 2003;361:763-73.

3. Brasil, Ministério da Saúde, Fundação Nacional de Saúde. Sarampo: das epidemias rumo à eliminação. Inf Mensal. 1994;VIII(5): $1-5$.

4. Siqueira MM, Castro-Silva R, Cruz C, Oliveira IC, Cunha GMC, Mello M, et al. Genomic characterization of wild-type measles viruses that circulated in different states in Brazil during the 1997 measles epidemic. J Med Virol. 2001;63:299-304
5. Brasil, Ministério da Saúde, Secretaria de Vigilância em Saúde. Situação das doenças transmissíveis no Brasil. Sarampo. Available from: http://dtr2001.saude.gov.br/svs/epi/ situacao doencas / situacao.htm\#sarampo [Web site]. Accessed 12 February 2005.

6. Pan American Health Organization. Measles and rubella surveillance in the Americas. Measles Wkly Bull. 2005;11(29);1-2.

7. Prevots RD, Parise MS, Segatto TCV, Siqueira MM, Santos ED, Ganter B, et al. Interruption of measles transmission in Brazil, 2000-2001. J Infect Dis. 2003;187 (Suppl 1):111-20.

8. Brasil, Ministério da Saúde. Sarampo. In: Brasil, Ministério da Saúde. Guia de vigilância epidemiológica. Available from: http://
dtr2001.saude.gov.br/svs/pub/GVE/GVE 0528C.htm [Web site]. Accessed 7 April 2006.

9. Minister of Public Works and Government Services Canada. Case definition for diseases under national surveillance. Available from: http://www.hc-sc.gc.ca/hpb/lcdc [Web site]. Accessed 12 February 2005. (Canada Communicable Disease Report Volume 26S3).

10. Cherry JD. Contemporary infectious exanthems. Clin Infect Dis. 1993;16:199-207.

11. Hummel KB, Erdman DD, Heath J, Bellini WJ. Baculovirus expression of the nucleoprotein gene of measles virus and utility of the recombinant protein in diagnosis enzyme immunoassays. J Clin Microbiol. 1992;30: 2874-80. 
12. Ratnam S, Tipples G, Head C, Fauvel M, Fearon M, Ward BJ. Performance of indirect immunoglobulin $\mathrm{M}$ ( $\mathrm{IgM}$ ) serology tests and IgM capture assays for laboratory diagnosis of measles. J Clin Microbiol. 2000;38:99-104.

13. Kuno G, Gomez I, Gubler DJ. Detecting artificial anti-dengue IgM immune complexes using an enzyme-linked immunosorbent assay. Amer J Trop Med Hyg. 1987;36(1):153-9.

14. Nogueira RMR, Miagostovich MP, Cavalcanti SMB, Marzochi KBF, Schatzmayr HG. Levels of IgM antibodies against dengue virus in Rio de Janeiro, Brazil. Res Virol. 1992;143:423-7.

15. Cubel RCN, Alferes ACR, Cohen BJ, Nascimento JP. Application to immunoglobulin M capture hemadherence assays of hemagglutination of monkey erythrocytes by native and recombinant human parvovirus B19 antigens. J Clin Microbiol. 1994;32:1997-9.

16. Ward KN, Gray JJ, Efstathiou S. Brief report: primary human herpesvirus 6 infection in a patient following liver transplantation from a seropositive donor. J Med Virol. 1989;28: 69-72.

17. Dean AG, Dean JA, Coulombier D, Burton $\mathrm{AH}$, Brendel KA, Smith DC, et al. Epi Info. Version 6. Atlanta: Centers for Disease Control and Prevention; 1994

18. Hutchins SS, Papania MJ, Amler R, Maes EF, Grabowsky M, Bromberg K, et al. Evaluation of the measles clinical case definition. J Infect Dis. 2004;189:S153-S159.

19. Dietz VJ, Nieburg P, Gubler DJ, Gómez I. Diagnóstico del sarampión según la definición de casos clínicos en zonas donde el dengue es endémico: repercusiones para la vigilancia y el control del sarampión. Bol Oficina Sanit Panam. 1994;116:11-7.

20. Tait DR, Ward KN, Brown DW, Miller E. Measles and rubella misdiagnosed in infants as exanthem subitum (roseola infantum). Br Med J. 1996;312:101-2.

21. Oliveira SA, Siqueira MM, Camacho LAB, Nogueira RM, Spinetti CCJ, Cubel Garcia $\mathrm{RCN}$, et al. The aetiology of maculopapular rash diseases in Niterói, State of Rio de Janeiro, Brazil: implications for measles surveillance. Epidemiol Infect. 2001;127:509-16.

22. Helfand RF, Chibi T, Biellik R, Shearley A, Bellini WJ. Negative impact of clinical misdiagnosis of measles on health workers' confidence in measles vaccine. Epidemiol Infect. 2003;132:7-10.

23. Ferson MJ, Young LC, Robertson PW, Whybin LR. Difficulties in clinical diagnosis of measles: proposal for modified clinical case definition. Med J Aust. 1995;163:364-6.

24. Ramsay M, Brugha R, Brown DWG. Surveillance of measles in England and Wales: implications of a national saliva testing programme. Bull World Health Organ. 1997;75: 515-21.

25. Lambert SB, Kelly HA, Andrews RM, Catton MC, Lynch PA, Leydon JA, et al. Enhanced measles surveillance during an interepidemic period in Victoria. Med J Aust. 2000;172. $114-8$

26. Wassilak SG, Orenstein WA, Strickland PL, Butler CA, Bart KJ. Continuing measles transmission in students despite a school-based outbreak control program. Amer J Epidemiol. 1985;122:208-17.

27. Hutchins SS, Markowitz LE, Mead P, Mixon D, Sheline J, Greenberg N, et al. A schoolbased measles outbreak: the effect of a selective revaccination policy and risk factors for vaccine failure. Am J Epidemiol. 1990;132: $157-68$

28. Cutts F, Brown DWG. The contribution of field tests to measles surveillance and control: a review of available methods. Rev Med Virol. 1995;5:35-40.

29. Nordin JD, Harpaz R, Harper P, Rush W. Syndromic surveillance for measleslike illnesses in a managed care setting. J Infect Dis. 2004; 189(Suppl 1):222-6.

30. Durrheim DN, Speare R. Measles elimination-a case definition to enhance surveillance. Commun Dis Intell. 2000;24(11):329-31.

31. Organización Panamericana de la Salud. Reunión del Grupo Especial de Expertos en Rubéola y Sarampión. Bol Inf PAI. 2004; XXVI(2):1-3.

32. Strebel PM, Papania MI, Halsey NA. Measles vaccine. In: Plotkin SA, Orenstein WA, eds. Vaccine. 4th ed. Philadelphia: Elsevier Inc.; 2004. Pp. 389-440.

Manuscript received 19 May 2005. Revised version accepted for publication 26 January 2006.

RESUMEN Objetivo. Evaluar la utilidad, en el Brasil, de la definición de "caso sospechado de sarampión", aplicada en pacientes con enfermedades exantemáticas, que se ha adoptado en el Brasil y en muchos otros países.

\section{Evaluación de la utilidad de una definición de "caso sospechado de sarampión": implicaciones para la vigilancia de la enfermedad}

Métodos. De enero de 1994 a diciembre de 2003, se examinó a pacientes con erupción cutánea aguda en dos grandes unidades de atención primaria y en un hospital general estatal en Niterói, en la zona metropolitana de la ciudad de Río de Janeiro, Brasil. Se usaron datos de la evaluación clínica y serológica para estimar la sensibilidad, especificidad, valor pronóstico de un resultado positivo (VPRP), y valor pronóstico de un resultado negativo (VPRN) aplicables a la definición de "caso sospechado de sarampión" adoptada en el Brasil, así como otras combinaciones de signos y síntomas; el resultado de pruebas serológicas se usó como parámetro de referencia. Usando la técnica de inmunoensayo enzimático, las muestras de suero se examinaron para detectar la presencia de anticuerpos de immunoglobulina $\mathrm{M}(\operatorname{IgM})$ contra el virus del sarampión.

Resultados. Se estudió a un total de 1221 pacientes con una enfermedad caracterizada por exantema cutáneo más otros signos y síntomas en diversas combinaciones. La definición de "caso sospechado" adoptada en el Brasil (erupción, fiebre y por lo menos un síntoma más, que puede ser tos, congestión nasal o conjuntivitis), tuvo una sensibilidad general de $100 \%$ y una especificidad de $58.7 \%$. La probabilidad de encontrar esa combinación de síntomas o signos fue 2,4 mayor entre los casos confirmados de sarampión que entre los casos de otras enfermedades exantemáticas. La definición de "caso sospechado" que se ha adoptado en el Brasil tuvo un VPRP de 6\% y un VPRN de $100 \%$. La presencia combinada de todos los cinco signos y síntomas tuvo la mayor especificidad, el mayor VPRP y la mayor razón de verosimilitud, tanto en niños ( $<15$ años de edad) como en adultos ( $\geq 15$ años). Eso se logró a expensas de la sensibilidad, que se redujo a $89 \%$, pero el VPRN siguió siendo muy alto.

Conclusiones. Nuestros resultados demuestran que la definición de "caso sospechado de sarampión" adoptada en el Brasil posee gran sensibilidad para la vigilancia de la enfermedad entre pacientes con enfermedades exantemáticas. No obstante, los elevados porcentajes de resultados positivos falsos que se detectaron podrían llevar a que se clasifiquen como sarampión, por error, muchas enfermedades exantemáticas de otra índole, lo que a su vez daría por resultado una mala orientación de las medidas de control y un aumento de su carestía.

Palabras clave Sarampión, exantema, diagnóstico diferencial, valor predictivo, vigilancia, Brasil. 